213

Received: February 20, 2016

Accepted: April 20, 2016
Macedonian Journal of Animal Science, Vol. 6, No. 1, pp 41-46 (2016)

In print: ISSN $1857-6907$

On line: ISSN $1857-7709$

UDC: $637.514 .5 .054 / .055: 635.252$

637.523.054/.055:635.262

Original scientific paper

\title{
THE INFLUENCE OF THE GARLIC EXTRACT ON THE CHEMICAL COMPOSITION, MICROBIOLOGICAL STATUS AND THE SENSORY CHARACTERISTICS OF MINCED PORK MEAT AND THE SEMI-DURABLE SAUSAGE
}

\author{
Aco Kuzelov ${ }^{1}$, Darko Andronikov ${ }^{1}$, Nako Taskov ${ }^{2}$, Elenica Sofijanova ${ }^{3}$, \\ Dušica Saneva $^{2}$, Dijana Naseva ${ }^{1}$ \\ ${ }^{1}$ Faculty of Agriculture, University, "Goce Delčev" in Štip, Republic of Macedonia \\ ${ }^{2}$ Faculty of Tourism and Business Logistics, University "Goce Delčev" in Štip, Republic of Macedonia \\ ${ }^{3}$ Faculty of Economics, University "Goce Delčev" in Štip, Republic of Macedonia \\ aco.kuzelov@ugd.edu.mk
}

\begin{abstract}
In this paper are given the results from the analysis of the influence of the garlic extract on the chemical composition, the microbiological status and the sensory characteristics of minced pork meat and the semi-durable sausage. In order to do the analysis, we prepared the following four groups of minced pork meat and sausage: group $1-$ without a garlic extract, group 2 - with garlic extract of $0.1 \mathrm{~g} / \mathrm{kg}$, group 3 - with a garlic extract of $0.2 \mathrm{~g} / \mathrm{kg}$, and group 4 - with a garlic extract of $0.3 \mathrm{~g} / \mathrm{kg}$. We randomly chose nine samples for the analyzis. Not one of the analyzed groups of minced pork meat and semi-durable sausage showed the presence of Clostridia, Escherichia coli, Salmonella or Listeria monocytogenes. The presence of other bacteria mostly bacilli was confirmed. The largest number of bacteria was confirmed in the controlled groups, while the smallest number of bacteria was in the group with a garlic extract of $0.3 \mathrm{~g} / \mathrm{kg}$. The controlled groups of minced pork meat and semi-durable sausage got very little sensory marks, while the best marked were the groups with an extract of $0.3 \mathrm{~g} / \mathrm{kg}$.
\end{abstract}

Key words: extract garlic; chemical composition; sensory properties

\section{ВЛИЈАНИЕ НА ЕКСТРАКТОТ ОД ЛУК ВРЗ ХЕМИСКИОТ СОСТАВ И МИКРОБИОЛОШКИОТ СТАТУС, СЕНЗОРНИТЕ ОСОБИНИ НА МЕЛЕНО СВИНСКО МЕСО И НАРОДЕН КОЛБАС}

Во трудот се дадени резултатите од испитувањата на влијанието на екстракт од лук врз хемискиот состав, микробиолошкиот статус и сензорите особини на мелено свинско месо и полутраен колбас. За таа цел беа подготвени по четири групи за испитување на меленото месо и колбасот, и тоа: група 1 - без додаток на екстракт од лук, група 2 - со додаток на $0,1 \mathrm{~g} / \mathrm{kg}$ екстракт, група 3 - со додаток на $0,2 \mathrm{~g} / \mathrm{kg}$ екстракт, и група 4 - со додаток на $0,3 \mathrm{~g} / \mathrm{kg}$ екстракт. Од секоја група по случаен избор беа земени по девет примероци кои беа испитувани. Во ниту една од испитуваните групи на мелено месо и полутраен колбас не беше утврдено присуството на Clostridia, Escherichia coli, Salmonela и Listeria monocytogenes. Беше утврдено само присуството на вкупен број бактерии, претежно бацили. Најголем вкупен број бактерии беше утврден кај контролните групи, а најмал кај групите со додаток на $0,3 \mathrm{~g} / \mathrm{kg}$ екстракт од лук. Најниски сензорни оценки добија контролните групи на мелено месо и полутрајниот колбас, а највисоки примероците од групите со додаток на $0,3 \mathrm{~g} / \mathrm{kg}$ екстракт.

Клучни зборови: екстракт лук; хемиски состав; сензорни особини

\section{INTRODUCTION}

Minced pork meat and the semi-durable sausage of the type produced home - National sausage are meat products. According to the book of regulations concerning the quality of minced pork meat, the meat preparations and the meat products (Official Gazette of RM no. 63 on 29.04.2013) needs to be prepared by grinding the first or second category of beef or pork with an added $1 \%$ salt, and the used quantity of muscle, fat and connective tissue need to match the category of meat.

The meat and the products filled with nutrients are considered an irreplaceable part of nutrition, but they are at the same time considered as risk products because of the risk of putrescence. 
The quality of these products decreases as the result of chemical and microbiological changes. The microbiological changes can appear as a result of a primary or secondary contamination with microorganisms. On the other hand, from the chemical changes often appears the lipid oxidation in the meat and the meat products and consequently the smell and the taste of these products becomes bad (Kanner, 1995; Aguirrezábal et al. 2000). In the recent years there are more and more researches that use gardening plants, parts of plants, herbs or their extracts that have antibacterial activity. The garlic and its extract is one of them. The major bioactive components of the garlic and its extract are the sulphur compounds such as alpine, diallyl sulphide, allyl disulphide and the allicin (Savić and Danon, 1985; Kumar and Berwal, 1998; Ankri and Milerman, 1999; Dragoev, 2004). In literature there is not much data on the influence of the garlic extract on the chemical and microbiological status, as well as the sensory characteristics of minced pork meat and the semi-durable sausage. The aim of our research is to analyze the influence of different garlic extract concentrations on the above mentioned characteristics of pork minced pork meat and the roughly grinded semi-durable sausage.

\section{MATERIAL AND WORK METHOD}

The materials used for the analysis were minced pork meat and the semi-durable National sausage (that is in the group of semi-durable and roughly grinded poached sausages), which were produced according to the book of regulations concerning the quality of minced pork meat, meat preparations and meat products (Official Gazette of RM no. 63 on 29. 04. 2013) by following all sanitary regulations. The semi-durable sausage was produced by the following recipe: second category beef $(25 \%)$, second category pork $(20 \%)$, hard fat tissue $(30 \%)$, meat stubs, and ice $(15 \%)$. Also to each kilogram we added 18 grams of nitrate salt for souse, 3 grams of phosphate, emulsifier of $0.020 \mathrm{~g} / \mathrm{kg}$, spices for sausage of $0.040 \mathrm{~g} / \mathrm{kg}$ (Koleks Ljubljana, Slovenia). The mixture was put into small pork intestines. We prepared four groups of minced pork meat and four groups of semidurable sausage.

Minced pork meat:

Group I - a controlled group without a garlic extract.

Group II - with a garlic extract of $0.1 \mathrm{~g} / \mathrm{kg}$.
Group III - with a garlic extract of $0.2 \mathrm{~g} / \mathrm{kg}$.

Group IV-with a garlic extract of $0.3 \mathrm{~g} / \mathrm{kg}$.

Semi-durable National sausage:

Group I - a controlled group without a garlic extract.

Group II - with a garlic extract of $0.1 \mathrm{~g} / \mathrm{kg}$.

Group III - with a garlic extract of $0.2 \mathrm{~g} / \mathrm{kg}$.

Group IV- with a garlic extract of $0.3 \mathrm{~g} / \mathrm{kg}$.

The garlic extract is produced by ECOM Food Industry Corporation Canada, with a microbiological clearance of $100 \%$ which means that the microbiological status is impeccable. The extract was added to minced pork meat during the mincing process, and it was added to the sausage during the production process. After the extract has been added, we pack the minced pork meat in plastic containers with the dimensions of $240 \times 130 \mathrm{~mm}$ and depth of $50 \mathrm{~mm}$. Then all the samples are vacuumed with a small multifunctional machine MULTIVAC (German product). After the vacuuming, we keep all the samples in a freezer on a temperature of $+4^{\circ} \mathrm{C}$. The microbiological analysis on minced pork meat was done on the first, third and fifth day since the samples were put in the freezer. The chemical and the sensory analysis were done on the final day of the containment.

After the sausage has been filled up and squeezed, we proceed with the processsing. The processing consisted of the following activities: drying of $35 \mathrm{~min}$, smoking of $20 \mathrm{~min}$ on $62^{\circ} \mathrm{C}$, boiling of $35 \mathrm{~min}$ on $78^{\circ} \mathrm{C}$ or until the product doesn't reach a temperature of $69-72^{\circ} \mathrm{C}$. The processing is followed by the process of vacuuming with Vebomak. Then, the sausages are kept in the freezer at a temperature of $+4{ }^{\circ} \mathrm{C}$. During that time, we made a microbiological analysis on the $1^{\text {st }}, 10^{\text {th }}, 20^{\text {th }}, 30^{\text {th }}$, $40^{\text {th }}$ and $50^{\text {th }}$ day. The chemical analysis was done immediately after the production. The sensory analysis was done once after the production, and at the end of the containment as well. All the minced pork meat groups were kept in the freezer on a temperature of $+4{ }^{\circ} \mathrm{C}$ after the vacuuming. The microbiological analysis was done the $1^{\text {st }}, 3^{\text {rd }}$ and $5^{\text {th }}$ day of the containment, while the chemical and the sensory analyzis were done on the final or the $5^{\text {th }}$ day.

\section{Chemical analysis}

The chemical tests were performed to test the water content in the sausage and minced pork meat by the method of ISO 1442/1998, the protein content by the Kjeldahl method, total fat by the ISO $1443 / 1992$ method, mineral substances by the ISO 936/1999. 


\section{Microbiological analysis}

The microbiological analysis of each sample was done on a material of $20 \mathrm{~g}$ that is homogenized with $180 \mathrm{ml}$ of sterile distilled water from which were made the appropriate dilutions. The number of bacteria is shown in $\log \mathrm{CFU} / \mathrm{g}$. The microbiological tests were ran for the presence of Proteus, Clostridia, E. coli, Salmonella, Listeria monocytogenes and the total number of bacteria. Proteus (bright green on temperature of $37^{\circ} \mathrm{C} / 24-48 \mathrm{~h}$ ), $E$. coli (bright green yolk lactose agar $42^{\circ} \mathrm{C} / 24-48 \mathrm{~h}$ ), Clostridia (agar $37^{\circ} \mathrm{C} / 24-48 \mathrm{~h}$ ), Salmonella (green bismuth sulphite agar $37^{\circ} \mathrm{C} / 24-48$ hours), Listeria monocytogenes (Fraser base Palcam agar, Oxoid) ISO $11290 / 2010$, total number of bacteria (nutrient agar $37^{\circ} \mathrm{C} / 24-48 \mathrm{~h}$ ) ISO 4833/2008.

\section{Sensory activities}

The sensory analysis was done by five experienced specialists. The analyzed sensory characteristics of the sausage were the following: outside appearance, cross-section appearance, colour, smell, taste, consistency and liquid release. On the other hand, we analyzed the following sensory characteristics of the minced pork meat: outside appearance, cross-section appearance, intersection colour and smell. The examiners had bread and water which means that after tasting each sausage they cleaned their mouth with water. The sensory analysis was done by using a 9-level scale approved by VNIMP Moscow.

\section{Statistic processing}

The received results were statistically processed by determining a mean value, variation measures, variation analysis, factor of the variation and statistic importance, Anova single factor (Excel MS Office 2003). Data were transformed into $\log _{10} \mathrm{CFU} / \mathrm{g}$ before comparison of means.

\section{RESULTS AND DISCUSSION}

The results of the analysis of the chemical content of the sausage are given in Table 1.

Table 1

Chemical content of the groups of the semi-durable sausage and the minced pork meat with or without garlic extract $(\mathrm{X} \pm S D)(\%)$

\begin{tabular}{lcccc}
\hline \hline Groups & Water & Proteins & Fats & Minerals \\
\hline \multirow{2}{c}{ Semi-durable sausage } & & \\
Controlled group I & $54.09 \pm 0.8$ & $17.2 \pm 0.22$ & $26.0 \pm 0.12$ & $2.71 \pm 0.10$ \\
Group II & $55.31 \pm 0.15$ & $17.2 \pm 0.22$ & $23.5 \pm 0.18$ & $3.99 \pm 0.22$ \\
Group III & $56.19 \pm 0.18$ & $14.5 \pm 0.15$ & $25.5 \pm 0.15$ & $3.81 \pm 0.28$ \\
Group IV & $55.12 \pm 0.10$ & $15.8 \pm 0.10$ & $26.0 \pm 0.12$ & $3.08 \pm 0.25$ \\
Significance & $\mathrm{NS}$ & $\mathrm{NS}$ & $\mathrm{NS}$ & $\mathrm{NS}$ \\
& & Minced pork meat & & \\
Controlled group I & $74.82 \pm 0.22$ & $20.88 \pm 0.28$ & $3.2 \pm 0.08$ & $1.1 \pm 0.12$ \\
Group II & $74.88 \pm 0.15$ & $20.55 \pm 0.22$ & $3.5 \pm 0.12$ & $1.07 \pm 0.18$ \\
Group III & $74.55 \pm 0.25$ & $19.98 \pm 0.10$ & $3.97 \pm 0.15$ & $1.05 \pm 0.05$ \\
Group IV & $73.82 \pm 0.12$ & $20.22 \pm 0.15$ & $4.22 \pm 0.22$ & $1.15 \pm 0.22$ \\
$\quad$ Significance & $\mathrm{NS}$ & $\mathrm{NS}$ & $\mathrm{NS}$ & $\mathrm{NS}$ \\
\hline \hline
\end{tabular}

NS - not significant

It can be seen from Table 1 that the largest percentage of water has group III $(56.19 \%)$, while the smallest percentage has group I $(54.09 \%)$. The smallest percentage of proteins has group III $(14.5 \%)$, while groups I and II have the largest percent $(17.2 \%)$. The percentage of fats is the larg- est in groups I and IV (26.0\%) and the smallest in group II $(23.5 \%)$. The percentage of minerals is the smallest in group I (2.71\%) and largest in group II $(3.99 \%)$. The minced pork meat has the biggest percentage of water in group II $(74.88 \%)$ and the smallest is in group IV $(73.82 \%)$. The proteins are 
most present in group I with $20.88 \%$ and at least present in group III with $19.98 \%$. The largest fats percentage has group IV $(4.22 \%)$ and the smallest has group I $(3.2 \%)$. The minerals are most present in group IV $(1.15 \%)$ and at least present in group III $(1.05 \%)$. There aren't any important differences among the analyzed groups of sausages and the analyzed groups of minced pork meat, which leads us to believe that the garlic extract has no influence on the chemical content of the semi-durable sausage and the minced pork meat. The larger water content in all the minced pork meat groups compared to the semi-durable sausage groups is natu- ral, because all kinds of meat have larger percentage of water compared to any processed meat product.

The results of the microbiological analysis of all the sausage and minced pork meat samples are given in Table 2. It can be seen from the table that there were n6t any Proteus, Clostridium, E. coli, Salmonella or Listeria monocytogenes during all stages of the test. The total number of bacteria was assessed and showed that most of them are bacilli. There is not a statistically important differences among the sausage groups concerning their microbiological status

Table 2

Microbiological status of the semi-durable sausage and minced pork meat groups with or without garlic extract $(\log C F U / g$.)

\begin{tabular}{cccccc}
\hline \hline Days & Controlled group I & Group II & Group III & Group IV & Significance \\
\hline \multicolumn{5}{c}{ Semi-durable sausage } \\
1 & 2.14 & 2.07 & 2.0 & 1.70 & NS \\
10 & 2.14 & 2.11 & 2.07 & 1.02 & NS \\
20 & 2.14 & 2.11 & 2.11 & 1.08 & NS \\
30 & 2.17 & 2.14 & 2.14 & 1.10 & NS \\
40 & 2.19 & 2.17 & 2.14 & 1.15 & NS \\
50 & 2.17 & 2.17 & 2.14 & 1.10 & NS \\
& & \multicolumn{2}{c}{ Minced pork meat } & & \\
1 & 3.53 & 3.51 & 3.41 & 3.20 & NS \\
3 & 3.50 & 3.36 & 3.30 & 3.32 & NS \\
5 & 3.39 & 2.96 & 3.30 & 3.17 & NS \\
\hline \hline
\end{tabular}

During the vacuuming process most of the bacteria was in the controlled group without a garlic extract, while the smallest number of bacteria was in group IV. The total number of bacteria didn't cross the recommended level of $7 \log$ CFU/g in none of the analyzed groups during the process of containment. Also the total number of bacteria didn't go beyond $3.53 \mathrm{log}$ CFU/g during all the period of the analysis.

Popović and Nikšić (2007); Nebedum et al. (2009) and Vlaić et al. (2012) discovered that the fresh garlic, the garlic powder and the garlic extract have an antibacterial effect during a continuous period of 21 day of the containment of sausages. Bekemblia et al. (2004) discovered that the garlic and the garlic extract have antibacterial and anti-fungicide effect. Kuzelov et al. (2015) discov- ered that the garlic extract applied to sausages in a concentrate of $0.3 \mathrm{~g} / \mathrm{kg}$ has good antibacterial effect.

The results from Tables 3 and 4 show us that immediately after the production process and the containment of all the groups of the tested sausages with a garlic extract had acceptable characteristics. A parameter of liquid release at the end of the production process wasn't present in any group of the tested sausages. Concerning the sensory characteristics there aren't any important differences among the tested groups expect in the characteristics of taste and smell. The characteristic of smell in group IV got high marks after the production process and at the end of the containment process compared to the other groups. Deviations in estimates between groups IV (9.45 and 8.90) and the con- 
trolled group (6.55 and 6.42), and group III (8.45 and 8.15$)$ and the controlled group (6.55 and 6.42) were observed. The sensory characteristic of taste in group IV immediately after the production and at the end of the containment got high marks $(9.10$ and 8.52) compared to the other tested groups. Group III got high marks (8.72 and 8.42) compared to the controlled group (6.45 and 6.28) and group II (6.58 and 6.28).

Table 3

The results from the sensory analysis immediately after the end of the production process with a garlic extract $(X \pm S D)$

\begin{tabular}{|c|c|c|c|c|}
\hline Sensory characteristics & Controlled group I & II & III & IV \\
\hline Outside appearance & $7.48 \pm 0.20$ & $7.45 \pm 0.18$ & $7.75 \pm 0.28$ & $7.80 \pm 0.12$ \\
\hline Cross-section appearance & $7.45 \pm 0.12$ & $7.28 \pm 0.40$ & $7.72 \pm 0.40$ & $7.85 \pm 0.28$ \\
\hline Colour of intersection & $6.80 \pm 0.12$ & $6.72 \pm 0.15$ & $6.50 \pm 0.15$ & $7.20 \pm 0.28$ \\
\hline Smell & $6.55 \pm 0.12$ & $7.40 \pm 0.12$ & $8.45 \pm 0.15$ & $9.45 \pm 0.18$ \\
\hline Tate & $6.45 \pm 0.15$ & $6.58 \pm 0.22$ & $8.72 \pm 0.20$ & $9.10 \pm 0.22$ \\
\hline Consistency & $7.45 \pm 0.28$ & $7.28 \pm 0.20$ & $7.40 \pm 0.15$ & $7.55 \pm 0.22$ \\
\hline Liquid release & / & / & / & / \\
\hline
\end{tabular}

Table 4

The results from the sensory analysis of the sausage groups at the end of the containment with a garlic extract after $50^{\text {th }}$ days $(X \pm S D)$

\begin{tabular}{lcccc}
\hline Sensory characteristics & Controlled group I & II & III & IV \\
\hline Outside appearance & $6.66 \pm 0.20$ & $6.85 \pm 0.25$ & $7.48 \pm 0.08$ & $7.55 \pm 0.18$ \\
Cross-section appearance & $5.90 \pm 0.22$ & $6.58 \pm 0.25$ & $6.72 \pm 0.12$ & $7.28 \pm 0.20$ \\
Colour of intersection & $6.80 \pm 0.45$ & $6.92 \pm 0.15$ & $7.20 \pm 0.12$ & $7.48 \pm 0.18$ \\
Smell & $6.42 \pm 0.15$ & $7.25 \pm 0.28$ & $8.15 \pm 0.18$ & $8.90 \pm 0.12$ \\
Tate & $6.28 \pm 0.18$ & $6.28 \pm 0.42$ & $8.42 \pm 0.18$ & $8.52 \pm 0.12$ \\
Consistency & $6.80 \pm 0.12$ & $7.42 \pm 0.15$ & $7.22 \pm 0.12$ & $7.50 \pm 0.28$ \\
Liquid release & $/$ & $/$ & $/$ & $/$ \\
\hline
\end{tabular}

The sensory marks of the minced pork meat with garlic extract that was kept on temperature of $+4^{\circ} \mathrm{C}$ were the highest for group 3 and lowest for the controlled group (Table 5). There aren't statis- tically important differences among the analyzed groups concerning all the sensory characteristics of the minced pork meat.

\section{Table 5}

The sensory analysis of the vacuumed groups of minced pork meat kept on temperature of $+4{ }^{\circ} \mathrm{C}$ after $5^{\text {th }}$ days $(X \pm S D)$

\begin{tabular}{l|c|c|c|c|}
\hline \hline Sensory activities & Controlled group I & Group II & Group III & Group IV \\
\hline Surface colour & $5 \pm 0.22$ & $7 \pm 0.15$ & $6 \pm 0.25$ & $7 \pm 0.20$ \\
\hline Colour of intersection & $5 \pm 0.20$ & $7 \pm 0.17$ & $6 \pm 0.18$ & $7 \pm 0.12$ \\
Smell & $6 \pm 0.18$ & $6 \pm 0.20$ & $5 \pm 0.28$ & $5 \pm 0.15$ \\
\hline \hline
\end{tabular}




\section{CONCLUSION}

It can be concluded from the above shown results that the garlic extract has no influence on the chemical content of the sausages or the minced pork meat. The garlic extract of 0.3 $\mathrm{g} / \mathrm{kg}$ that was applied to the sausages and the minced pork meat has an influence on the microbiological status and the sensory characteristics of taste and smell of the sausages, and it has an influence on the sensory characteristics of surface colour and intersection colour of the minced pork meat.

\section{REFERENCES}

[1] Aguirrezábal, M. M., Mateo, J., Domínguez, M. C., Zumalacárregui, J. M.: The effect of paprika, garlic and salt on rancidity in dry sausages. Meat Science, 54, pp 77-81 (2000).

[2] Ankri, S., Mirelman, D.: Antimicrobial properties of allicin from garlic. Microbes and Infection, pp 125-129 (1999).

[3] Bekemblia, N.: Antimicrobial activity of essential oil extracts of various onions (Allium cepa) and garlic (Allium sativum). LWT Food Sci. Technol., 37, pp 263-268 (2004).
[4] Dragoev, S: Development of Technology in Meat and Fish Industry. Academic Publishing, UFT Plovdiv, pp 96-112 (2004).

[5] Kanner, J.: Oxidative processes in meat and meat products quality implications. Meat Science, 36, pp 169-174 (1995).

[6] Kumar, M., Berwal, J. S.: Sensitivity of food pathogens to garlic (Allium sativum). Journal of Applied Microbiology, 84, pp 213-215 (1998).

[7] Kuzelov A., Andronikov, D., Naseva, D., Marenceva, D: Effect of garlic extract on the microbiological status and sensory properties of pork minced meat. International Conference on Food Science Engineering and Technology, 2015, pp 20-23

[8] Nebedum, J., Ajeigbe K. O., Nwobodo, E., Uba, C., Adesanya, O., Fadera, O., Ofusori, D.: Comparative study of the ethanolic extracts of four Nigerian plants against some pathogenic microorganisms. Res. J. of Medicinal Plant, 3 (1), pp. 23-28 (2009).

[9] Popović G., Nikšić M.: Growth of pathogenic bacteria Listeria monocitogenes in salads with the addition of basil. Journal on Processing and Energy in Agriculture PTEP, Vol. 11, No. 1-2, pp 27-31 (2007).

[10] Savić, I., Danon, J.: Spices of the Meat Processing. Veterinary Faculty in Belgrade, 1982, pp 25-27..

[11] Vlaić S., Takać, A., Balaž, J.: Uticaj ekstrakta belog luka (Allium sativum L.) na fitopatogene bakterije. Zbornik radova sa 36, smotre naučnih radova studenata poljoprivrede $i$ veterinarske medicine sa međunarodnim učešćem, 2012, pp 15-20. 